\title{
The Effect of Idiosyncratic Shocks on Labor Market Outcomes of Informal Households in Indonesia
}

\author{
(Kesan Kejutan Idiosinkratik ke atas Hasil Pasaran Buruh bagi Isi Rumah Tidak Formal di \\ Indonesia)
}

\author{
Rokhedi Priyo Santoso \\ Universitas Islam Indonesia \\ Jaka Sriyana \\ Universitas Islam Indonesia
}

ABSTRACT

The informal households are considered to be the most vulnerable to any idiosyncratic shocks rather than the formal ones. Unfortunately, the established literatures mostly do not specifically emphasize the analysis of this group. This study contributes to literatures on the specific analysis on the effects of idiosyncratic shocks namely sickness, death, and job loss on the labor market outcomes of informal households in Indonesia. The analytical method used is the estimation of panel data with a fixed-effect model to control for unobserved heterogeneity. The data consists of 3,755 informal households taken from Indonesia Family Life Survey (IFLS) in the period of 2007/2008 and 2014/2015. Estimated results indicate that illness and job loss significantly reduce earning of self-employed households, while the number of working hours remains unchanged. On the other hand, the working hours of causal households in agriculture significantly increase when a family member is sick. Even though they work longer, their earning remains constant. These findings indicate that shocks cause a significant decline in the economic welfare of the informal households in Indonesia.

Keywords: Idiosyncratic shocks; labor market outcomes; informal

ABSTRAK

Isi rumah tidak formal dianggap sebagai kumpulan yang paling terancam kepada mana-mana kejutan idioskinkratik berbanding isi rumah formal. Walau bagaimanapun, literatur sedia ada kebanyakannya tidak menekankan analisis mengenai kumpulan ini. Kajian ini menyumbang kepada literatur melalui analisis khusus kesan kejutan idiosinkratik iaitu kesakitan, kematian dan kehilangan pekerjaan ke atas hasil pasaran buruh bagi isi rumah tidak formal di Indonesia. Kaedah analitik yang digunakan adalah penganggaran data panel dengan model efek tetap bagi mengawal keheteregonan yang tidak dicerap. Data terdiri daripada 3755 isi rumah tidak formal yang diperolehi daripada Tinjauan Hidup Keluarga Indonesia dalam tempoh 2007/2088 dan 2014/2015. Keputusan penganggaran menunjukkan bahawa kesakitan dan kehilangan pekerjaan mempengaruhi pengurangan pendapatan bagi isi rumah yang bekerja sendiri, manakala bilangan jam bekerja tidak berubah. Selain itu, bilangan jam bekerja bagi isi rumah dalam sektor pertanian meningkat secara siginifikan apabila ahli keluarga sakit. Walaupun mereka bekerja lebih lama, pendapatan mereka akan kekal tidak berubah. Dapatan kajian ini menunjukkan bahawa kejutan menyebabkan penurunan yang ketara dari segi kebajikan ekonomi bagi isi rumah tidak formal di Indonesia.

Kata kunci: Kejutan idiosinkratik; hasil pasaran buruh; tidak formal

\section{INTRODUCTION}

The idiosyncratic shocks have different impacts on different social groups. The informal sectors are considered to be the most vulnerable group because of their inherent disadvantageous characteristics. The informal sectors are characterized as all economic activities which are not covered by any legal regulations or formal arrangements (Chen 2007). Working in informal jobs is associated with higher underemployment (Nazara 2010). Working in these sectors does not require high education, skill, technology, and capital. People work in these sectors because there is no choice or, in other words, the situation forces them to work in these sectors for the reason of survival. Gender inequality and precarious works are common in informal jobs (Chen 2001). Also, any social protection in these sectors are excluded (Günther \& Launov 2012; Perry et al. 2007). 
As the consequences, the informal sectors are prone to various risks and contingencies (ILO 2014). That is why they are more vulnerable to poverty.

A change in labor market behaviors is one of the responses of informal sectors to any economic shocks caused by idiosyncratic risks. Those risks are specific and only inherent in certain individuals or households such as illness, death, or job loss of any household members (UNDP 2011). Illness makes a person have lower or even no productivity. If there is a family member who is sick, high medical cost is required, especially for the one who does not have any health insurance. Besides, the death of family members may also cause a large proportion of total expenditure, especially for poor households. Health care before death, burial processions, and various forms of salvation require substantial cost. Meanwhile, job and earning loss can be the result of any crop loss, business bankruptcy, or labor market shocks. All of those risks cost much higher to the income of informal households in the short run, and potentially deteriorate the welfare in the long run. This study analyzes the effect of idiosyncratic shocks namely illness, death, and job loss on the labor market outcomes of informal households in Indonesia. The change in labor market outcomes is specifically represented by the change in labor earnings and working hours.

Indonesia is a country that has very large informal sectors. The existence of the sectors is considered as part of the problems on the rigidity of the formal labor market in Indonesia (Kurniasih, 2017). Their presence is still considered as underemployment, which is part of the problems of poverty in Indonesia (Nazara, 2010). In 2018, the total numbers of informal sector workers were 70.4 million. It was about $57 \%$ of the Indonesian working population. They consisted of self-employed $(34 \%)$, self-employed with unpaid/family workers (28\%), unpaid family workers $(21 \%)$, a casual worker in non-agriculture $(10 \%)$ and a casual worker in agriculture (7\%) (Table 1).

While the number of informal jobs are high, the quality is contrary. Human resources in informal sectors are considered having low quality. About $47 \%$ informal workers have education only in the level of high/vocational school. Moreover, almost a half of the informal workers have only elementary education (Table 2). Most of the informal workers are located in the rural rather than in the urban area (BPS 2018).

A number of studies that establishes the relation between economic shocks and labor market outcomes in Indonesia (Genoni 2012; Gertler \& Gruber 2002; Gertler, Levine, \& Moretti 2009; Sparrow et al. 2014; Swaminathan \& Lillard 2000)as well as other developing countries (Ajefu 2017; Asfaw \& von Braun 2004; Skoufias, Quisumbing 2002) are mostly using total formal and informal households as the unit of observation. As the researchers have noted from the previous studies they did not analyze specifically the labor market responses of informal household toward the idiosyncratic shocks. Thus, this study contributes to the literature by separating the informal household to the formal one in its response to the idiosyncratic shocks. This separate unit of observation is relevant since the disadvantageous characteristics inherent in the informal households including the low level of skills, the insufficient educational background, and the low income has caused this group to be more vulnerable to idiosyncratic shocks than the formal ones. In addition, limited accessibility of households to financial institutions, underdeveloped insurance systems, and the lack of social protection in most developing countries make the effects of shock more serious, not only for short term but also long term.

This study uses rich information from Indonesian Family Life Survey (IFLS) on the economic disruptions experienced by informal households in the last 5 years. These economic disruptions include a serious illness suffered by head of household/main breadwinner who require hospital care and periodical treatment, the death of the head of household/main breadwinner or other household members, job loss or business failure experienced by household members such as failed harvests, and reduction in income due to crop failure or a decrease in production rate. These kinds of economic hardships represent the idiosyncratic risks of illness, death, and job loss, respectively.

The paper is organized as follows: the next section provides literature review on the relation between idiosyncratic shocks and labor market outcomes as well as the coping strategies by households. It is then followed by the section about the methods that explore the data source of Indonesia Family Life Survey (IFLS) as well as the empirical strategies. The empirical results elaborating the previous works are presented in the last section before the conclusion.

\section{LITERATURE REVIEW}

Critical study on how individual's working hours and wage response to illness in Indonesia is conducted by Gertler and Gruber (2002). This research estimates the changes in health status, which are measured by the activities of daily living (ADL) index on wage and consumption expenditure. The symptoms of sickness do not reduce the working hours, but the symptoms of chronic diseases can reduce up to 1 working hour per week. Even worse, the effect of ADL from being completely healthy to being sick is significant, in which it can reduce up to 31 working hours per week. In other words, any decrease in disability doing one ADL will reduce 2.8 working hours or more than $7.6 \%$ of the total. Meanwhile, the effect of total ADL changes causes a reduction in wages up to $\mathrm{Rp} 20,170$ per hour. This amount is approximately equal to the average income 
TABLE 1. Population Aged 15 and over by Main Employment Status 2018 (.000)

\begin{tabular}{llcccccc}
\hline No. & Employment Status & Category & 2014 & 2015 & 2016 & 2017 & 2018 \\
\hline 1 & Self-employed & Informal & 20,487 & 19,530 & 20,015 & 23,147 & 23,623 \\
2 & Self-Employed with Unpaid/Family Worker & Informal & 19,276 & 18,188 & 19,451 & 18,025 & 19,548 \\
3 & Employed with Paid Worker & Formal & 4,177 & 4,072 & 4,380 & 3,955 & 4,290 \\
4 & Employees & Formal & 42,382 & 44,434 & 45,828 & 48,047 & 49,232 \\
5 & Casual Worker in Agriculture & Informal & 5,094 & 5,086 & 5,500 & 5,848 & 5,206 \\
6 & Casual Worker in Non Agriculture & Informal & 6,406 & 7,449 & 6,966 & 7,158 & 6,973 \\
7 & Unpaid/Family Worker & Informal & 16,806 & 16,060 & 16,273 & 14,842 & 15,134 \\
& Total & & 114,628 & 114,819 & 118,412 & 121,022 & 124,005 \\
\hline
\end{tabular}

Source: Indonesian Labor Survey 2019

TABLE 2. Population Aged 15 and over by Education Attainment 2018 (.000)

\begin{tabular}{lcccccccc}
\hline \multirow{2}{*}{ Employment Status } & \multirow{2}{*}{ Category } & \multicolumn{2}{c}{ Up to Elementary } & \multicolumn{3}{c}{ High School } & \multicolumn{3}{c}{ Higher Education } & \multirow{2}{*}{ Total } \\
\cline { 3 - 7 } & & Total & $\%$ & Total & $\%$ & Total & $\%$ & \\
\hline Self-employed & Informal & 11,643 & $23 \%$ & 10,857 & $19 \%$ & 1,123 & $7 \%$ & 23,623 \\
Self-Employed with Unpaid/Family Worker & Informal & 11,943 & $24 \%$ & 6,993 & $12 \%$ & 612 & $4 \%$ & 19,548 \\
Employed with Paid Worker & Formal & 1,309 & $3 \%$ & 2,283 & $4 \%$ & 698 & $5 \%$ & 4,290 \\
Employees & Formal & 9,804 & $19 \%$ & 27,307 & $47 \%$ & 12,121 & $80 \%$ & 49,232 \\
Casual Worker in Agriculture & Informal & 3,989 & $8 \%$ & 1,208 & $2 \%$ & 8 & $0 \%$ & 5,206 \\
Casual Worker in Non Agriculture & Informal & 3,858 & $8 \%$ & 3,066 & $5 \%$ & 50 & $0 \%$ & 6,973 \\
Unpaid/Family Worker & Informal & 7,913 & $16 \%$ & 6,729 & $12 \%$ & 492 & $3 \%$ & 15,134 \\
Total & & 50,458 & & 58,443 & & 15,104 & & 124,005 \\
\hline
\end{tabular}

Source: Indonesian Labor Survey, 2019

in the period of survey baseline. On the other hand, the inability to do one ADL has caused wages to decrease up to $10 \%$.

Swaminathan and Lillard (2000) use health variables as latent variables to predict health effects on wages and labor force participation in Indonesia. The use of this model is intended to anticipate that health variables are endogenous, and to overcome the sample selection bias. The latent variables use seven indicators of the ability of an individual's physical mobility. To measure wages, two approaches are used to avoid measurement errors. With control variables such as education level and age, the effect of latent health variables on wages is not significant for women, whereas the impact of the health latent variable is significant on the level of labor participation after controlling the wage level.

Individuals or households who are sick and uncovered by insurance experience a decline in welfare. Genoni (2012) investigates the impact of changes in individual income and consumption in Indonesia when they are sick. The sickness is measured by changes in the ability to perform certain physical functions in the peak of a productive aged individual sample. The result shows that sickness reduces income significantly. Meanwhile, the effect of sickness does not reduce the consumption level significantly because the households may use an adjustment mechanism from their relatives for smoothing consumption.

A study by Sparrow et al. (2014)examined the impact of illness on the income of formal and informal households in Indonesia from the household panel data of Susenas (Socio-economic Household Survey) during 2003-2004. Using the fixed effects Poisson models, the result shows that there is a negative effect of the shock on income through the medical expenses channel. In the case of poor informal sectors, the illness reduces the labor income. The poor household is hardly able to maintain their consumption levels. Meanwhile, for nonpoor and formal sectors, the shock negatively affects the earning from their self-employed business activities. The implication of the study requires the reformation of the public health care financing scheme. The alternative way to protect the potential income loss of any shocks is by creating a higher opportunity for formal employment, especially for the poor rural community.

Under the lack of well-developed financial market, the existence of microfinance institutions and programs help poor families to insure their consumption. In Indonesia, a large part of the poor population is less likely to have any saving accounts. It is clear that 
health shocks have enormous potential financial risks especially for poor families. They can suffer from large income loss due to the larger reduction in working hours and productivity. Gertler, Levine and Moretti (2009) had a research whether access to any microfinance institutions helps the Indonesian poor to smoothen their consumption level. The results of the study showed that the families that reside far away from any financial institutions will largely suffer adverse health shock than those who stay at nearer microfinance providers like BRI (Rural Microfinance Banks). The study also analyzed that these correlations are not due to statedependent preferences. By using the data from both who work with and without any physical labor before the illness, the study finds that those who have higher assets and closer access to the financial institution will be more likely to have stable consumptions. It implies that access to financial institution will determine the self-insurance against the adverse health shock. The study further examines the omitted variable to reconfirm the correlation between health changes, consumption changes, and the household location to any microfinance institutions. Thus, based on these findings, the important policy implication is that the government should promote microfinance and micro saving programs to help the poor face the negative effect of health shock. A small financial assistant to cover the enrollment cost will help to wider the access to any micro-financial institutions and programs. This policy is to complete the traditional policy of giving subsidy, mandates, or any other poor health family insurances.

The vulnerability of households to any health shock is worsened by the fact that health financing in Indonesia is lower compared to that in other countries. World Bank (2005) reported that on average it is only equal to USD 16 per capita per year in 2001. This is caused by a lower per capita spending on health by both individuals and government. Ironically, the burden of health costs is mostly borne by individuals. Individuals must finance an average of $75 \%-80 \%$ of total health financing, in which they have to do this financing as soon as they receive the health services. This condition is also exacerbated by the low utilization of the insurance system which only covers a small part of the community, especially the formal sectors. The communities that have already protected by insurance are only one-third of the population. Although they have been covered by the insurance, they still have to pay health cost immediately when they get health services or when the bill is out of the insurance limit. As many as $20 \%$ of the poor population only receive health subsidies from the government, in which less than $10 \%$, while the wealthy receives $40 \%$ of total health subsidies. It is because the utilization rate of the poor people in accessing health services subsidized by the government is still lower.

Not only affecting the adult market labor sectors, the idiosyncratic risks also having a potential hazard to child labor. Kharisma and Bayu (2017) investigated the various idiosyncratic risks to the child labor and their school attendance rates in Indonesia. An increasing number of the child labor is encouraged by the shocks like crop losses, illness of any members of the household, fall of crop commodity prices and production, and death of the head or any members of the family. They only have limited access to both formal and informal sectors. However, family assets play an important role to reduce the number of child labor. It is different to what happened in Vietnam, farmers cope with the volatility of international coffee prices by substituting children and adolescent workers for adults on the farm (Beck, Singhal, \& Tarp 2019).

Kim and Prskawetz (2010) analyzed the further impact of idiosyncratic shocks on household consumption, education expenditure, and fertility in Indonesia. This study answers the question of whether child human capital investment expenditure and fertility are used as mechanisms for consumption smoothing of households in Indonesia. This study uses seven types of self-reported economic hardships, where the results show the effect of job loss which reduces education consumption and expenditure. On the contrary, the impact of the death of family members or natural disasters increases consumption. This shows that coping mechanism sometimes causes over-compensated consumption during difficult times. Another significant result is that each shock has different effects depending on the adjustment of economic conditions and demographic behavior. The different result will require a mixed system of social security schemes.

Besides, idiosyncratic risk may also be the result from the death of family member and job/earning loss. Parinduri (2014) examined how the impact of family hardships experienced by micro and small business owners in Indonesia. The shock does influence the growth of their businesses. Using a sample of micro and small business owners in Indonesia, the study finds that the death of business owners or family members reduces the value of business and assets up to 30 percent. This decrease on assets is even greater and significant on a smaller scale of business. This shows that the development of micro and small businesses might be hampered by a limited internal source of finance.

Meanwhile the study on the impact of idiosyncratic shock in agriculture in Indonesia was conducted by Cameron \& Worswick (2003). This study uses the 1993 Indonesian Family Life Survey to study labor supply responses under crop loss situation. Around 41.6\% self-reported experienced crop losses, so they had to take extra jobs. This coping strategy is associated to prevent consumption reduction. In terms of the number of hours, the family members do not increase the labor supply, but they switch their labor activities into nonagriculture market sectors. Different with this result, the study from Berloffa and Modena (2013) founds that the 
poor households increase labor supply to compensate the income from the crop loss shock. Moreover, they can save half of this extra income from agriculture.

Not only affecting the labor market outcomes, the shock of idiosyncratic having also further implication on human capital development. Fitzsimons (2007) studied the effect of shocks on educational attainment in Indonesia. The shocks in this study are decomposed into aggregate village and idiosyncratic risks. Without access to any formal insurance, the shock has adverse consequences for children's education as self-insurance. In small rural villages where there is no formal insurance market, the idiosyncratic risks do not affect the children's education. On the other hand, the village aggregate risks have a negative effect on educational attainment. The argument underlying this condition is that the village aggregate risks are not easy to diversify. The caution policy implication is that the government should be aware to avoid the self-insurance mechanism, and not to crowd the formal ones out.

A number of previous works also studied the effect of idiosyncratic shock on labor market outcomes and how they cope with the shock in developing countries. Under the shock, a consumption smoothing is rarely smooth because their income is too low and volatile. This situation is common in lower-income countries. Asfaw and von Braun (2004) studied the effect of illness on consumption smoothing in a rural household in Ethiopia. Furthermore, the study also analyzes the mechanism of risk-sharing among the intra and interhouseholds to insure their consumption. The result shows that illness shock harms consumption, especially for non-food consumption. The food consumption that comes from their production or external sources is well-insured against the shock. However, the risksharing mechanism does not work to insure the nonfood consumption. The head of household changed status from healthy to unhealthy reduces the non-food consumption up to more than 24 percentage points. This study result implies the urgency of health insurance or improvement of existing local risk-sharing mechanism for the poor households to offset the potential loss from any income shocks, like illness.

In most developing countries, health shock is the most common idiosyncratic risk that forces the households to fall into poverty. In the insured $40 \%$ threshold, the catastrophic health expenditure represents $60.95 \%$ of households' total monthly nonfood expenditure in Togo (Atake \& Amendah 2018). Moreover, the absence of any formal insurance market increases the vulnerability into poverty about $39.04 \%$, $33.69 \%$, and $69.03 \%$ in three Sub-Saharan Africa (SSA) countries, namely, Burkina Faso, Niger and Togo. Poverty is the leading cause of economic loss from health shocks as the poorer cannot afford to purchase sufficient quantities of good quality food, preventive and curative health care, and education (Atake 2018).
In spite of important contribution by India's informal economy, the tattered conditions have increased the expenditure of health shocks in various ways (Ahmad \& Aggarwal 2017). The informal sectors must spend more than $5 \%$ of threshold on their health expenditure and this spending pushes $7.12 \%$ informal households in poverty. This finding indicates that informal households are vulnerable to any health shocks. In another study in India, severity of the effect of idiosyncratic and covariate shocks depends on the risk management strategy of each household. The community types of rural region in India are the drive of the livelihood precariousness of agricultural shocks (Berchoux, Watmough, Hutton, \& Atkinson 2019). In general, households will do several ways like withdrawing savings, seeking remittances from migrant family members, taking loan from formal and informal lenders and selling their existing assets and participating in government sponsored welfarebased programs. The non-poor rural households are able to cope with the shocks by building up the safety net. However, the extremely poor family is unable to cope with adverse effect of the shock since they could not access any support from informal financial sources. At the same time, the government welfare program has failed to reassure this grief situation during the shock (Pradhan \& Mukherjee 2018). The study is in line with the finding of Skoufias et al. (2002) that studied about to which extent the households are able to insure their consumption using formal and informal mechanisms during the shock in five countries including Bangladesh, Ethiopia, Mali, Mexico and Russia. The insurance of consumption is measured by the growth rate of household consumption covaries with the growth rate of household income. The result shows that the non-food consumption is less insured than the food consumption from the reversed effect of the idiosyncratic risks. At the community level, the food consumption is more likely to be covered by informal coping strategies than that of non-food consumption. The level of utilization of the strategies varies among households. The poorer the households, the lower the utilization of mechanism relying on the initial wealth as collateral is. On the other study, Ajefu (2017) shows that the informal insurance strategies only play in limited roles to reduce the reversed effect of shock on household income. Using fixed effect and profit model on Nigerian Household Panel Survey data, this study examines the effect of idiosyncratic risk on household consumption and informal coping strategies for consumption smoothing. The result shows that the informal insurance strategies only plays in limited roles to reduce the reversed effect of shock on household income compared to other coping strategies. Moreover, under the prevalence of poverty and limited social safety net program, the health shock and death have negative impact on rural food and non-food consumption in Nigeria because of increasing medical expenditure (Onisanwa \& Olaniyan 2019). 
Many other studies on the idiosyncratic shock effect are also conducted in developed economies that have had an established social protection system. Pelkowski and Berger (2004) investigate the effect of temporary and permanent illness on employment, annual working hours and hourly wages using lifetime record of The Health and Retirement Study. The permanent health problem decreases the female workers' wages larger while, on the contrary, it reduces the working hours significantly for the male workers. The peak of the male health problem is at the ' 40 s when it affects the most. In contrast, the largest negative consequence for females is in the ' 30 s. In addition, Zucchelli, Jones, Rice and Harris (2010) find that health shock is the main determinant of workers to early quit their jobs in Australia. The adverse health effect forces the probability of men to an early resignation by 50 to 320 percent. It is also responsible for women to consider an early quit with the probability of 68 to 74 percent. Align with this study, García-Gómez (2011) investigates the effect of health problem on the labor market outcomes in 9 European countries using the matching technique of the European Community Household Panel. The individual with a health problem is more likely to quit the job and transit into disability. The largest significant impact is in Netherland, while the smallest is in France. The different social security systems may explain these cross-country differences.

The well-established social security system is needed to mitigate the adverse effect of any economic hardships. Using the German Socio-Economic Panel (1984-2002) data and matching methods, Lechner \& Vazquez-Alvarez (2011) analyze the effect of individual disability on the labor market outcomes. The results indicate that under the German social security system, the reduction in individual employment opportunities is quite low, that is around 9 to 13 . The extent of effect depends on the degree of disability.

Wage shock may also affect the intra-household insurance model. Zhang (2014) investigates the joint labor supply decision of married couples in responding to each other's wage shock in the United States. Different from the focus of existing studies of intra-household insurance that only consider the wage shock of husbands or wives only, the study modeled the insurance against the shock from both partners. When both partners are working, any wage shock will increase the wives' labor supply in response to the adverse shock of the husband wage. Furthermore, the wives will earn more non-labor income when they are no longer working. Such kind of joint labor supply decision is responsible to provide extra smoothing effect by reducing the instability of income by about 2 to $9 \%$. The joint labor supply decision may indicate the existence of the Added Worker Effect (AWE). In Chile, for example, when a male partner suffers a health shock such as new cases of arthritis, it generates an AWE that depends on age cohorts. The probability of women to entry the labor force over past three years rises by 50 percentage points when their 1844 year old husband is diagnosed with arthritis (Acuña, Acuña, \& Carrasco 2019).

Meanwhile, the shock of job loss causes significant income loss because of being unemployed which, in turn, affects the consumption level and welfare. It is common in advanced countries that during the unemployment spell, they will get the unemployment insurance. Typically, the studies on unemployment insurance cover how the individual behavior changes on the job search. The insurance, on the other hands, may reduce the labor supply of household member during a husband unemployment period. Cullen and Gruber (2000) investigate how this state-contingent income will affect the response of wives' labor supply. The result shows that the unemployment insurance crowds the spouse income out. It means that for every dollar the unemployed receives, the wives will earn 73 cents less. In developing countries like Indonesia, in contrast, this unemployment insurance has not existed at least by 2020 .

The impact of job loss does not only correspond to the labor market issues, but also has serious social problems. Eliason and Storrie (2009) examine the effect of losing the job to mortality. In all establishment closures of Sweden in 1987 and 1988 , the study uses the employer-employee data to identify the displaced workers. In subsequent of the first four years of job loss, a man has a 44 percent increase in overall mortality risk, while leaving no effect on overall woman's mortality. However, the cause-specific mortality increases about twofold both for man and woman. This mortality specifically caused by alcohol-related death. In a rural area, the crop loss risk is responsible for the shock for the rural household especially in the agriculture sector.

\section{METHODOLOGY}

The sample of analysis used in this study is informal households. Household data is taken from the Indonesia Family Life Survey (IFLS) Wave 4 and 5. The IFLS is an on-going longitudinal survey in Indonesia that surveys more than 30,000 individuals living in 13 provinces in Indonesia, and the sample represents about $83 \%$ of the Indonesian population. The IFLS 4 is the fourth wave survey conducted in 2007/2008 by RAND in collaboration with Gadjah Mada University and Survey Meter. Meanwhile, IFLS 5 was conducted in $2014 / 2015$.

The IFLS distinguishes the worker types into eight subcategories that can be categorized into two bigger classes including formal and informal workers. The formal worker consists of self-employed with permanent workers, government workers, and workers in private sectors, whereas the informal worker consists of self- 
employed, self-employed with unpaid family workers or temporary workers, casual workers in agriculture, non-agricultural casual workers, and unpaid family workers. This study excludes the unpaid family workers because the earning data is not available.

The definitions of each variable used in the estimation model are available in Table 3 below.

The basic specifications model used for estimation refers to the Mincerian earnings function (Mincer 1974) and for the structural equation adopts the fixed-effect specification model developed by Gertler and Gruber (2002). Moreover, this study takes the advantage of fixedeffect model that allows us to control for unobserved heterogeneity (Wooldridge 2013). Specifically, the first-differencing in fixed-effect rules out correlation from omitted unobserved individual characteristics such as preferences and health endowments that might confound identifying the effect of shocks on labormarket outcomes. However, there may be unobserved correlates of changes in earning and changes in shocks that confound identification. We include a set of community fixed effects to control for one major source of spurious correlation that is the local economy community shocks such as weather. It potentially affects both changes in labor market outcomes and changes in shock.

In addition, since the data were collected in $2007 / 2008$ and $2014 / 2015$ it allows us to examine shocks, labor earning, and labor supply changes over a two-year period. The data were collected for each household at the same point in the year in both waves, so that we condition out seasonality effects in our fixedeffects models.
We estimate labor supply, earnings, and shocks equations using the following fixedeffect specifications. The indexes of $i$ and $j$ in all equations explain the individual household and community, respectively. Whereas the coefficient of $\alpha_{j}$ is the community fixed effect and $e_{i j}$ is the error terms. Equation (1) estimates the effect of idiosyncratic shocks i.e. illness, death, and job loss and its interactions to the labor earning of informal households.

$$
\begin{aligned}
{\ln \text { Earning }_{i j}=} & \alpha_{j}+\beta_{1} \text { death }_{i j}+\beta_{2} \text { jobloss }_{i j}+\beta_{3} \text { illness }_{i j}+ \\
& \beta_{4} \text { death }^{*} \text { jobloss }_{i j}+\beta_{5} \text { death }^{*} \text { illness }_{i j}+ \\
& \beta_{6} \text { jobloss }^{*} \text { illness }_{i j}+\sum_{k=1}^{K} \gamma_{k} \text { demographic }_{i j k}+e_{i j}
\end{aligned}
$$

Meanwhile, the Equation (2) estimates the effect of idiosyncratic shocks i.e. illness, death, and job loss and its interactions to the working hours of informal households.

$$
\begin{aligned}
\text { Hours }_{i j}=\quad & \alpha_{j}+\beta_{1} \text { deat }_{i j}+\beta_{2} \text { jobloss }_{i j}+\beta_{3} \text { illness }_{i j}+ \\
& \beta_{4} \text { death }^{*} \text { jobloss }_{i j}+\beta_{5} \text { death }^{*} \text { illness }_{i j}+ \\
& \beta_{6} \text { jobloss }^{*} \text { illness }_{i j}+\sum_{k=1}^{K} \gamma_{k} \text { demographic }_{i j k}+e_{i j}
\end{aligned}
$$

To compare the effect of the shocks between informal and formal households, we also estimate labor earning and working hours of the total households as

\begin{tabular}{|c|c|c|}
\hline symbol & variable & definition \\
\hline illness & health shock & $\begin{array}{l}\text { serious illness suffered by head of household / main breadwinner who require } \\
\text { hospital care or treatment of periodical; and suffered serious illnesses that require } \\
\text { treatment or hospital care periodic treatment. }\end{array}$ \\
\hline death & death shock & $\begin{array}{l}\text { the death of head of household / main breadwinner, and other household member } \\
\text { deaths. }\end{array}$ \\
\hline jobloss & job loss shock & failed harvests, and crop failure or a decrease in production rate \\
\hline earning & labor earning & total hourly earning received by head of household from job market \\
\hline hours & labor supply & total weekly working hours spent by head of household in job market \\
\hline Demographic: & demographic variables & \\
\hline$-e d u c$ & - education level & education level of household head \\
\hline$-\operatorname{sex}$ & $-\operatorname{sex}$ & gender of household head \\
\hline$-a g e$ & - age & age of household head \\
\hline -married & - marital status & marital status of household head \\
\hline - member & - family member & the number of family member in a household \\
\hline -urban & -location & location the household resides \\
\hline$-j a v a$ & - region & region the household resides \\
\hline$-y e a r$ & - periode & period-effect specification \\
\hline
\end{tabular}
dependent variables and adding dummy variables of informality and their interaction terms from each Equation (1) and (2). Specifically, the estimation for the effect of idiosyncratic shock on labor earning and

TABLE 3. The Definition of Variables 
working hours of total households are presented in Equation (3) and (4), respectively.

$$
\begin{aligned}
& \ln \text { Earning }_{j}=\quad \alpha_{j}+\delta_{1} \text { informal }_{i j}+\beta_{1} \text { death }_{i j}+\beta_{2} \text { jobloss }_{i j}+\beta_{3} \text { illness }_{i j}+ \\
& \beta_{4} \text { informal }^{*} \text { death }_{i j}+\beta_{5} \text { informal } * \text { jobloss }_{i j}+ \\
& \beta_{6} \text { informal }^{*} \text { illness }_{i j}+\sum_{k=1}^{K} \gamma_{k} \text { demographic }_{i j k}+e_{i j} \\
& \text { Hours }_{j}=\alpha_{j}+\delta_{1} \text { informal }_{i j}+\beta_{1} \text { death }_{i j}+\beta_{2} \text { jobloss }_{i j}+\beta_{3} \text { illness }_{i j}+. \\
& \beta_{4} \text { informal }^{*} \text { death }_{i j}+\beta_{5} \text { informal }^{*} \text { jobloss }_{i j}+ \\
& \beta_{6} \text { informal } * \text { illness }_{i j}+\sum_{k=1}^{K} \gamma_{k} \text { demographic }_{i j k}+e_{i j}
\end{aligned}
$$

Informal variables in Equation (3) and (4) indicate the status of household whether informal or formal. Using dummy variable, it is one if informal and zero if formal household. The interactions of informal and each shocks are to show the severity of the idiosyncratic risk effect of informal households compared to formal ones.

\section{RESULTS AND DISCUSSION}

The summary statistic of the data used in this study is described in Table 4. Like in other developing countries, illness is the most prevalence case of idiosyncratic shocks in Indonesia. The mean of earning is about Rp. $14,910.80$ per hour, while the on average the informal household spend about 40.82 hours per week to work. From this summary statistic, it reinforces the notion that the level of education of most informal household is low. The years of education is about 5.96 years or equivalent to elementary education. Whereas for the age variable, the mean is about 49.16 years old.

The estimation results of idiosyncratic shock effect on self-employed and self-employed with unpaid worker are presented in Table 5. Job loss experienced by family members of self-employed decreases the household income by $85 \%$, or it can be stated that they lost most of their income. The possible argument that can explain this finding is because the job is the primary source of household income. Thus, almost all income will be lost. This lost implies a serious problem since they might be responsible for covering the living costs of their family members. This findings is consistent to the previous works (Gertler \& Gruber 2002; Sparrow et al. 2014), but the statistics is much higher because this study only focus on the informal sector. On the other hand, illness is the most often shock experienced by informal households compared to death and job loss. From Table 5, it can also be seen that the sick of a family member of self-employed household causes labor earning to fall by $55 \%$, while their working hours remain constant. A possible explanation for the constant working hours is the increase working hour of other healthy families to replace the sick one or added work effect (Ajefu 2017; Swaminathan \& Lillard 2000). The one must still work even though they are sick. The decreasing labor earning also indicates that household productivity falls due to the illness.

For the self-employed with unpaid family workers or temporary worker households, they run their own business and immediately receive income for the work. They sometimes act as owners as well as workers. Income earned is irregular, depending on business conditions. If they do not work, then they will not receive any income at all. Based on the estimation, when they lose their jobs, the earning they receive are $189 \%$ lower than before the shock. The possibility response to this shock is that they can withdraw their savings or even

TABLE 4. Summary Statistics

\begin{tabular}{lccccc}
\hline & measurement unit & mean & standard deviation & minimum & maximum \\
\hline Earning & rupiah/hour & $14,910.80$ & $307,879.99$ & 0 & $23,255,800$ \\
Working hours & hours/week & 40.82 & 22.59 & 0 & 168 \\
Education & year & 5.96 & 4.08 & 0 & 19 \\
Sex & dummy & 0.85 & 0.36 & 0 & 1 \\
Age & year & 49.16 & 13.49 & 16 & 101 \\
Marrital status & dummy & 0.84 & 0.37 & 0 & 1 \\
Family member & person & 3.99 & 1.77 & 1 & 1 \\
Urban/rural & dummy & 0.41 & 0.49 & 0 & 1 \\
Java/non-Java & dummy & 0.53 & 0.50 & 0 & 1 \\
Death & dummy & 0.01 & 0.11 & 0 & 1 \\
Jobloss & dummy & 0.01 & 0.11 & 0 & 1 \\
Ilness & dummy & 0.04 & 0.19 & & 1 \\
$N$ & & 7,512 & & 0 & 1 \\
\hline
\end{tabular}

Source: authors' own analysis 
sell their assets to cover their needs. Besides, the illness also causes labor earning of self-employed with unpaid workers to be lower by $85 \%$ compared to the situation when they were healthy. This can be understood because the characteristics of these households are that they mostly run all of their own business by themselves. So that when they are sick, their income will be reduced the most. These results also support the previous study of Parinduri (2014).

If the member of the household is sick, the ability to work becomes significantly reduced. Their ability to run business is also strongly influenced by age that

TABLE 5. Estimation of Self-Employed and Self-Employed with Unpaid Workers

\begin{tabular}{|c|c|c|c|c|c|c|c|c|}
\hline \multirow{2}{*}{ Variables } & \multicolumn{4}{|c|}{ Self-Employed } & \multicolumn{4}{|c|}{ Self-Employed with Unpaid Worker } \\
\hline & ln_earning & ln_earning & hours & hours & ln_earning & ln_earning & hours & hours \\
\hline & (1) & $(2)$ & (3) & (4) & $(5)$ & (6) & (7) & $(8)$ \\
\hline \multirow[t]{2}{*}{ educ } & 0.00 & 0.00 & 0.21 & 0.23 & -0.02 & -0.02 & 0.45 & 0.45 \\
\hline & $(0.03)$ & $(0.03)$ & $(0.48)$ & $(0.48)$ & $(0.04)$ & $(0.04)$ & $(0.41)$ & $(0.41)$ \\
\hline \multirow[t]{2}{*}{ male } & 0.39 & 0.40 & 0.96 & 1.11 & -0.02 & 0.00 & 1.59 & 1.54 \\
\hline & $(0.31)$ & $(0.31)$ & $(4.24)$ & $(4.25)$ & $(0.36)$ & $(0.36)$ & $(3.52)$ & $(3.54)$ \\
\hline \multirow[t]{2}{*}{ age } & 0.05 & 0.05 & 0.29 & 0.30 & $0.15 * * *$ & $0.15^{* * *}$ & 0.40 & 0.40 \\
\hline & $(0.04)$ & $(0.04)$ & $(0.57)$ & $(0.57)$ & $(0.05)$ & $(0.05)$ & $(0.45)$ & $(0.45)$ \\
\hline \multirow[t]{2}{*}{$\operatorname{age}^{\wedge} 2$} & -0.00 & -0.00 & -0.00 & -0.00 & $-0.00 * * *$ & $-0.00 * * *$ & -0.00 & -0.00 \\
\hline & $(0.00)$ & $(0.00)$ & $(0.01)$ & $(0.01)$ & $(0.00)$ & $(0.00)$ & $(0.00)$ & $(0.00)$ \\
\hline \multirow[t]{2}{*}{ married } & -0.28 & -0.28 & -1.62 & -1.77 & -0.48 & -0.50 & 3.63 & 3.68 \\
\hline & $(0.26)$ & $(0.26)$ & $(3.60)$ & $(3.62)$ & $(0.34)$ & $(0.34)$ & (3.39) & $(3.41)$ \\
\hline \multirow[t]{2}{*}{ member } & 0.08 & 0.08 & 0.34 & 0.35 & -0.00 & -0.00 & -0.39 & -0.39 \\
\hline & $(0.05)$ & $(0.05)$ & $(0.70)$ & $(0.70)$ & $(0.05)$ & $(0.05)$ & $(0.47)$ & $(0.47)$ \\
\hline \multirow[t]{2}{*}{ urban } & -0.19 & -0.19 & $-5.11 *$ & $-5.09 *$ & -0.27 & -0.27 & -1.53 & -1.52 \\
\hline & $(0.22)$ & $(0.22)$ & $(3.08)$ & $(3.08)$ & $(0.34)$ & $(0.34)$ & $(3.36)$ & $(3.36)$ \\
\hline \multirow[t]{2}{*}{ java } & 1.75 & 1.75 & 16.55 & 16.47 & -1.33 & -1.33 & 9.07 & 9.08 \\
\hline & $(2.23)$ & $(2.23)$ & $(31.01)$ & (31.03) & $(2.52)$ & $(2.52)$ & $(25.21)$ & $(25.22)$ \\
\hline \multirow[t]{2}{*}{ death } & 0.25 & 0.23 & 1.71 & 1.15 & 0.64 & 0.71 & -3.43 & -3.58 \\
\hline & $(0.48)$ & $(0.49)$ & $(6.53)$ & $(6.66)$ & $(0.54)$ & $(0.55)$ & $(5.26)$ & (5.36) \\
\hline \multirow[t]{2}{*}{ jobloss } & $-0.85^{*}$ & $-0.85^{*}$ & 3.07 & 3.04 & $-1.89 * * *$ & $-1.89 * * *$ & -2.15 & -2.16 \\
\hline & $(0.47)$ & $(0.47)$ & $(6.50)$ & $(6.50)$ & $(0.71)$ & $(0.71)$ & (7.06) & (7.06) \\
\hline \multirow[t]{2}{*}{ illness } & $-0.54^{* *}$ & $-0.55^{* *}$ & 3.35 & 3.14 & $-0.85 * *$ & $-0.82 * *$ & -1.13 & -1.20 \\
\hline & $(0.27)$ & $(0.28)$ & (3.79) & $(3.82)$ & $(0.34)$ & $(0.34)$ & $(3.34)$ & $(3.37)$ \\
\hline \multirow[t]{2}{*}{ dyear } & $0.68 * * *$ & $0.68^{* * *}$ & -1.56 & -1.56 & $0.58^{* * *}$ & $0.57 * * *$ & $-2.14 * *$ & $-2.13 * *$ \\
\hline & $(0.10)$ & $(0.10)$ & (1.39) & (1.39) & $(0.11)$ & $(0.11)$ & $(1.04)$ & $(1.04)$ \\
\hline \multirow[t]{2}{*}{ co.death\#co.jobloss } & & 0.00 & & 0.00 & & 0.00 & & 0.00 \\
\hline & & $(0.00)$ & & $(0.00)$ & & $(0.00)$ & & $(0.00)$ \\
\hline \multirow[t]{2}{*}{ c.death\#c.illness } & & 0.39 & & 13.95 & & -1.76 & & 3.88 \\
\hline & & $(2.29)$ & & $(31.78)$ & & $(2.61)$ & & $(26.09)$ \\
\hline \multirow[t]{2}{*}{ co.jobloss\#co.illness } & & 0.00 & & 0.00 & & 0.00 & & 0.00 \\
\hline & & $(0.00)$ & & $(0.00)$ & & $(0.00)$ & & $(0.00)$ \\
\hline \multirow[t]{2}{*}{ Constant } & $5.23 * * *$ & $5.23 * * *$ & 27.17 & 26.91 & $4.89 * * *$ & $4.91 * * *$ & 23.06 & 23.03 \\
\hline & $(1.73)$ & $(1.73)$ & $(23.87)$ & $(23.89)$ & $(1.78)$ & $(1.78)$ & $(17.76)$ & (17.77) \\
\hline Observations & 1,650 & 1,650 & 1,664 & 1,664 & 1,923 & 1,923 & 1,941 & 1,941 \\
\hline R-squared & 0.09 & 0.09 & 0.01 & 0.01 & 0.09 & 0.09 & 0.02 & 0.02 \\
\hline
\end{tabular}


represents the experience, where the older the person, the higher the earning. However, the increase in earnings will be diminishing further. This is indicated by the coefficient of the squared age variable, which is negative. Interestingly, the working hours are only slightly reduced even though there are family members who have lost their jobs or experienced illness. The estimation results show that the decrease in working hours of one family member must be compensated by an increase in the number of working hours by other family members. This is to cover the household living cost that arises because of a shock. This finding is

TABLE 6. Estimation of Casual Workers: Agriculture and Non-Agriculture

\begin{tabular}{|c|c|c|c|c|c|c|c|c|}
\hline \multirow{3}{*}{ Variables } & \multicolumn{4}{|c|}{ Self-Employed } & \multicolumn{4}{|c|}{ Self-Employed with Unpaid Worker } \\
\hline & ln_earning & ln_earning & hours & hours & ln_earning & ln_earning & hours & hours \\
\hline & (1) & (2) & (3) & (4) & $(5)$ & (6) & (7) & $(8)$ \\
\hline \multirow[t]{2}{*}{ educ } & 0.16 & 0.16 & 0.82 & 0.82 & $0.13 * *$ & $0.13 * *$ & 0.85 & 0.85 \\
\hline & $(0.11)$ & $(0.11)$ & $(1.22)$ & $(1.22)$ & $(0.06)$ & $(0.06)$ & $(0.96)$ & $(0.96)$ \\
\hline \multirow[t]{2}{*}{ male } & $1.50 *$ & $1.50^{*}$ & -0.63 & -0.63 & 0.37 & 0.37 & $25.08 * * *$ & $25.08 * * *$ \\
\hline & $(0.79)$ & $(0.79)$ & $(8.98)$ & $(8.98)$ & $(0.58)$ & $(0.58)$ & $(8.99)$ & (8.99) \\
\hline \multirow[t]{2}{*}{ age } & -0.05 & -0.05 & -1.32 & -1.32 & 0.04 & 0.04 & -0.79 & -0.79 \\
\hline & $(0.12)$ & $(0.12)$ & (1.33) & (1.33) & $(0.07)$ & $(0.07)$ & (1.10) & $(1.10)$ \\
\hline \multirow[t]{2}{*}{$\operatorname{age}^{\wedge} 2$} & 0.00 & 0.00 & 0.02 & 0.02 & -0.00 & -0.00 & 0.01 & 0.01 \\
\hline & $(0.00)$ & $(0.00)$ & $(0.01)$ & $(0.01)$ & $(0.00)$ & $(0.00)$ & $(0.01)$ & $(0.01)$ \\
\hline \multirow[t]{2}{*}{ married } & $-1.56^{* *}$ & $-1.56^{* *}$ & 3.42 & 3.42 & -0.41 & -0.41 & -7.26 & -7.26 \\
\hline & $(0.68)$ & $(0.68)$ & $(7.71)$ & (7.71) & $(0.45)$ & $(0.45)$ & (6.96) & $(6.96)$ \\
\hline \multirow[t]{2}{*}{ member } & -0.09 & -0.09 & -0.13 & -0.13 & $-0.13 *$ & $-0.13^{*}$ & 0.96 & 0.96 \\
\hline & $(0.13)$ & $(0.13)$ & (1.48) & (1.48) & $(0.07)$ & $(0.07)$ & (1.13) & (1.13) \\
\hline \multirow[t]{2}{*}{ urban } & -1.05 & -1.05 & -5.19 & -5.19 & -0.05 & -0.05 & $-9.88^{*}$ & $-9.88 *$ \\
\hline & $(0.64)$ & $(0.64)$ & (7.34) & $(7.34)$ & $(0.34)$ & $(0.34)$ & $(5.24)$ & $(5.24)$ \\
\hline \multirow[t]{2}{*}{ java } & - & - & - & - & $-8.60 * * *$ & $-8.60 * * *$ & -18.52 & -18.52 \\
\hline & & & & & (1.62) & (1.62) & (25.08) & (25.08) \\
\hline \multirow[t]{2}{*}{ death } & 0.71 & 0.71 & $30.63 * *$ & $30.63 * *$ & 0.52 & 0.52 & 9.55 & 9.55 \\
\hline & $(1.24)$ & $(1.24)$ & (14.18) & (14.18) & $(1.55)$ & $(1.55)$ & $(24.08)$ & $(24.08)$ \\
\hline \multirow[t]{2}{*}{ jobloss } & -1.28 & -1.28 & -1.00 & -1.00 & 0.21 & 0.21 & -14.58 & -14.58 \\
\hline & $(2.22)$ & $(2.22)$ & $(25.30)$ & (25.30) & $(0.64)$ & $(0.64)$ & (9.99) & (9.99) \\
\hline \multirow[t]{2}{*}{ illness } & 0.36 & 0.36 & 1.10 & 1.10 & -0.61 & -0.61 & 2.30 & 2.30 \\
\hline & $(0.83)$ & $(0.83)$ & $(9.45)$ & $(9.45)$ & $(0.47)$ & $(0.47)$ & $(7.31)$ & $(7.31)$ \\
\hline \multirow[t]{2}{*}{ dyear } & $0.60 * *$ & $0.60 * *$ & -3.63 & -3.63 & $0.82 * * *$ & $0.82 * * *$ & 2.79 & 2.79 \\
\hline & $(0.27)$ & $(0.27)$ & $(3.05)$ & $(3.05)$ & $(0.17)$ & $(0.17)$ & $(2.62)$ & $(2.62)$ \\
\hline \multirow[t]{2}{*}{ co.death\#co.jobloss } & & 0.00 & & 0.00 & & 0.00 & & 0.00 \\
\hline & & $(0.00)$ & & $(0.00)$ & & $(0.00)$ & & $(0.00)$ \\
\hline \multirow[t]{2}{*}{ c.death\#c.illness } & & 0.00 & & 0.00 & & 0.00 & & 0.00 \\
\hline & & $(0.00)$ & & $(0.00)$ & & $(0.00)$ & & $(0.00)$ \\
\hline \multirow[t]{2}{*}{ co.jobloss\#co.illness } & & 0.00 & & 0.00 & & 0.00 & & 0.00 \\
\hline & & $(0.00)$ & & $(0.00)$ & & $(0.00)$ & & $(0.00)$ \\
\hline \multirow[t]{2}{*}{ Constant } & $8.86^{* * *}$ & $8.86^{* * *}$ & 48.06 & 48.06 & $12.05 * * *$ & $12.05 * * *$ & 47.30 & 47.30 \\
\hline & $(2.90)$ & $(2.90)$ & $(33.05)$ & $(33.05)$ & $(2.22)$ & $(2.22)$ & $(34.41)$ & $(34.41)$ \\
\hline Observations & 197 & 197 & 197 & 197 & 386 & 386 & 386 & 386 \\
\hline R-squared & 0.19 & 0.19 & 0.11 & 0.11 & 0.36 & 0.36 & 0.09 & 0.09 \\
\hline
\end{tabular}

Note: Standard errors in parentheses

$*$, **, and $* * *$ indicate significant at the $10 \%, 5 \%$ and $1 \%$ level, respectively

Source: authors' own analysis 
consistent to the previous works of Dalton and LaFave (2017)and Demenet (2016). This first study found that reallocating home production is the one that the mechanism to mitigate the loss and the burden of the shock. It might be transmitted throughout family networks. While the later found that intra-household labor reallocation are able to mitigate the direct labor supply decrease.
Table 6 summarizes the estimation results of idiosyncratic shock effect on casual in agriculture and non-agriculture households. The casual worker in agriculture household is someone who works for other people or employers in the agricultural sector. They receive wages either in the form of a daily wage or the wholesale salary system. These workers are included farm laborers who plant, maintain, and harvest the

TABLE 7. Estimation of All Informal Households

\begin{tabular}{|c|c|c|c|c|}
\hline Variables & $\begin{array}{c}\text { In_earning } \\
\text { (1) }\end{array}$ & $\begin{array}{c}\text { In_earning } \\
\text { (2) }\end{array}$ & $\begin{array}{c}\text { hours } \\
(3)\end{array}$ & $\begin{array}{c}\text { hours } \\
\text { (4) } \\
\end{array}$ \\
\hline \multirow[t]{2}{*}{ educ } & 0.01 & 0.01 & 0.77 & 0.80 \\
\hline & $(0.02)$ & $(0.02)$ & $(0.93)$ & $(0.93)$ \\
\hline \multirow[t]{2}{*}{ male } & 0.20 & 0.20 & $13.95 *$ & $14.26^{*}$ \\
\hline & $(0.15)$ & $(0.16)$ & $(7.68)$ & $(7.70)$ \\
\hline \multirow[t]{2}{*}{ age } & $0.10 * * *$ & $0.10 * * *$ & $1.88^{*}$ & $1.88^{*}$ \\
\hline & $(0.02)$ & $(0.02)$ & (1.01) & $(1.01)$ \\
\hline \multirow[t]{2}{*}{$\operatorname{age}^{\wedge} 2$} & $-0.00 * * *$ & $-0.00 * * *$ & $-0.02 * *$ & $-0.02 * *$ \\
\hline & $(0.00)$ & $(0.00)$ & $(0.01)$ & $(0.01)$ \\
\hline \multirow[t]{2}{*}{ married } & -0.18 & -0.17 & -1.26 & -1.33 \\
\hline & $(0.14)$ & $(0.14)$ & (7.11) & (7.11) \\
\hline \multirow[t]{2}{*}{ member } & 0.01 & 0.01 & -0.56 & -0.55 \\
\hline & $(0.02)$ & $(0.02)$ & $(1.20)$ & $(1.20)$ \\
\hline \multirow[t]{2}{*}{ urban } & 0.03 & 0.03 & -4.86 & -4.89 \\
\hline & $(0.13)$ & $(0.13)$ & $(6.44)$ & $(6.44)$ \\
\hline \multirow[t]{2}{*}{ java } & -1.18 & -1.17 & 40.82 & 40.77 \\
\hline & $(0.76)$ & $(0.76)$ & (38.12) & (38.13) \\
\hline \multirow[t]{2}{*}{ death } & 0.26 & 0.29 & 2.81 & 1.67 \\
\hline & $(0.26)$ & $(0.27)$ & $(12.65)$ & (13.26) \\
\hline \multirow[t]{2}{*}{ jobloss } & -0.36 & -0.38 & -17.94 & -13.92 \\
\hline & $(0.26)$ & $(0.27)$ & $(13.05)$ & $(13.56)$ \\
\hline \multirow[t]{2}{*}{ illness } & $-0.39 * *$ & $-0.43 * * *$ & 7.36 & 7.88 \\
\hline & $(0.15)$ & $(0.16)$ & (7.58) & (7.73) \\
\hline \multirow[t]{2}{*}{ dyear } & $0.51 * * *$ & $0.51 * * *$ & $-6.69 * * *$ & $-6.73 * * *$ \\
\hline & $(0.05)$ & $(0.05)$ & $(2.50)$ & $(2.50)$ \\
\hline \multirow[t]{2}{*}{ co.death\#co.jobloss } & & $-2.74 *$ & & -10.86 \\
\hline & & $(1.49)$ & & $(74.66)$ \\
\hline \multirow[t]{2}{*}{ c.death\#c.illness } & & 0.59 & & 30.70 \\
\hline & & $(0.98)$ & & $(48.78)$ \\
\hline \multirow[t]{2}{*}{ co.jobloss\#co.illness } & & 1.82 & & -68.90 \\
\hline & & $(1.15)$ & & $(57.66)$ \\
\hline \multirow[t]{2}{*}{ Constant } & $5.52 * * *$ & $5.52 * * *$ & $104.54 * * *$ & $104.16^{* * *}$ \\
\hline & $(0.71)$ & $(0.71)$ & $(35.27)$ & $(35.27)$ \\
\hline Observations & 7,407 & 7,407 & 7,468 & 7,468 \\
\hline R-squared & 0.06 & 0.06 & 0.01 & 0.01 \\
\hline
\end{tabular}

Note: Standard errors in parentheses

$*, * *$, and $* * *$ indicate significant at the $10 \%, 5 \%$ and $1 \%$ level, respectively

Source: authors' own analysis 
TABLE 8. Estimation of All Households (Informal and Formal)

\begin{tabular}{|c|c|c|c|c|}
\hline Variables & $\begin{array}{c}\text { ln_earning } \\
\text { (1) }\end{array}$ & $\begin{array}{c}\text { ln_earning } \\
\text { (2) }\end{array}$ & $\begin{array}{l}\text { hours } \\
\text { (3) }\end{array}$ & $\begin{array}{l}\text { hours } \\
\text { (4) }\end{array}$ \\
\hline \multirow[t]{2}{*}{ informal } & $-0.30 * * *$ & $-0.30 * * *$ & $-6.59 * * *$ & $-6.39 * *$ \\
\hline & $(0.05)$ & $(0.05)$ & $(2.48)$ & $(2.55)$ \\
\hline \multirow[t]{2}{*}{ educ } & $0.02 *$ & $0.02 *$ & -0.03 & -0.03 \\
\hline & $(0.01)$ & $(0.01)$ & $(0.58)$ & $(0.58)$ \\
\hline \multirow[t]{2}{*}{ male } & $0.23 * * *$ & $0.24 * * *$ & 4.85 & 4.88 \\
\hline & $(0.09)$ & $(0.09)$ & $(4.82)$ & $(4.82)$ \\
\hline \multirow[t]{2}{*}{ age } & $0.09 * * *$ & $0.09 * * *$ & $1.65 * *$ & $1.64 * *$ \\
\hline & $(0.01)$ & $(0.01)$ & $(0.65)$ & $(0.65)$ \\
\hline \multirow[t]{2}{*}{$\operatorname{age}^{\wedge} 2$} & $-0.00 * * *$ & $-0.00 * * *$ & $-0.02 * * *$ & $-0.02 * * *$ \\
\hline & $(0.00)$ & $(0.00)$ & $(0.01)$ & $(0.01)$ \\
\hline \multirow[t]{2}{*}{ married } & -0.12 & -0.12 & 0.48 & 0.49 \\
\hline & $(0.08)$ & $(0.08)$ & $(4.43)$ & $(4.43)$ \\
\hline \multirow{2}{*}{ member } & 0.01 & 0.01 & 1.10 & 1.11 \\
\hline & $(0.01)$ & $(0.01)$ & $(0.80)$ & $(0.80)$ \\
\hline \multirow[t]{2}{*}{ urban } & 0.05 & 0.05 & -2.15 & -2.17 \\
\hline & $(0.07)$ & $(0.07)$ & $(3.97)$ & $(3.97)$ \\
\hline \multirow{2}{*}{ java } & -0.41 & -0.41 & 3.01 & 3.12 \\
\hline & $(0.29)$ & $(0.29)$ & (16.07) & (16.08) \\
\hline \multirow[t]{2}{*}{ death } & -0.16 & $-0.48 * *$ & 2.79 & -0.56 \\
\hline & $(0.15)$ & $(0.23)$ & $(8.19)$ & (12.72) \\
\hline \multirow[t]{2}{*}{ jobloss } & -0.18 & -0.15 & -12.29 & -9.36 \\
\hline & $(0.14)$ & $(0.21)$ & $(7.63)$ & (11.35) \\
\hline \multirow[t]{2}{*}{ illness } & -0.12 & 0.09 & 3.74 & 6.48 \\
\hline & $(0.09)$ & $(0.15)$ & $(5.00)$ & $(8.03)$ \\
\hline \multirow[t]{2}{*}{ dyear } & $0.57 * * *$ & $0.57 * * *$ & $-4.50 * * *$ & $-4.50 * * *$ \\
\hline & $(0.03)$ & $(0.03)$ & (1.66) & (1.66) \\
\hline \multirow[t]{2}{*}{ co.death\#co.jobloss } & & $0.53^{*}$ & & 5.51 \\
\hline & & $(0.29)$ & & (16.16) \\
\hline \multirow[t]{2}{*}{ c.death\#c.illness } & & -0.05 & & -5.37 \\
\hline & & $(0.28)$ & & $(15.23)$ \\
\hline \multirow[t]{2}{*}{ co.jobloss\#co.illness } & & $-0.32 *$ & & -4.34 \\
\hline & & $(0.18)$ & & (10.09) \\
\hline \multirow[t]{2}{*}{ Constant } & $5.82 * * *$ & $5.81 * * *$ & $149.14 * * *$ & $149.11 * * *$ \\
\hline & $(0.36)$ & $(0.36)$ & (19.90) & (19.91) \\
\hline Observations & 16,200 & 16,200 & 16,296 & 16,296 \\
\hline R-squared & 0.10 & 0.10 & 0.01 & 0.01 \\
\hline
\end{tabular}

Note: Standard errors in parentheses

$*, * *$, and $* * *$ indicate significant at the $10 \%, 5 \%$ and $1 \%$ level, respectively

Source: authors' own analysis

crops. The characteristics of this casual work are that it requires more physical power rather than non-physical. Empirically this is proven from the estimation results (Table 6) where male workers receive wages 150 percent higher compared to female workers. The shock of the death of a family member causes working hours to increase by 30 hours per week. Ironically, even though working hours are longer, their income is relatively unchanged. In other words, to get the same amount of money, they have to spend more time to work. The 
death of family members causes income to decrease. Assuming leisure is normal, then a decrease in income will decrease leisure time which will further increase the number of working hours. This compensating labor supply is consistent with the previous study by Berloffa and Modena (2013).

Illness, death or job loss by the one of a family member in casual jobs in the non-agriculture household do not affect the changes in labor earning nor working hours. In contrast, education influences labor earning significantly. This does not happen in other types of informal households where education does not considerably influence the earning. This can be understood because they work with another party, where the level of education can be a signal of the productivity of these workers (Spence 1973). Every additional year of education increases the hourly earnings of casual workers in non-agriculture by 13 percent. Besides, male works 25 hours per week longer compared to their counterparts.

Table 7 presents the idiosyncratic shock effect when all informal households are aggregately estimated. It is the only illness that affects the decreasing informal household hourly earnings up to $43 \%$. Furthermore, the effect of concurrent death and job loss on earning reduction is even more significant. These shocks reduce the earning by $270 \%$. To compensate for the loss of income, they might withdraw savings or sell their assets. Meanwhile, death and job loss shocks separately had no significant effect on changes in working hours of informal households.

The level of hourly earnings for informal households is also influenced by the average age of the head of the household, rather than by the level of education. This empirical fact can be easily understood because of working in the informal sector. The experience is more important than formal education (Chen 2001; ILO 2014). Of course, this is very different from the formal sector that demands formal education. The variable of age and squared age is to represent work experience. An additional age increase wages up to 10 percent but at diminishing rates due to physical depreciation. The age also affects significantly on working hours, where a year of extra age increases working hours up to 2 hours per week with decreasing rates. Male workers also have 14 hours/week longer working hours than that of females.

This study also estimated the model on total households consisting of both formal and informal (Table 8). To compare the formal and informal household, it uses dummy variables of informality and its interaction terms. On average, the informal household hourly earnings are 30 percent lower than that of formal hourly earnings. This finding also supports the previous studies from Gertler and Gruber (2002); Sparrow et al. (2014). Moreover, the working hours of informal households are also 6.59 hours/week shorter than that of the formal one.
From the previous informal estimation, education does not affect wages. If the estimation is conducted on all total formal and informal households, however, education is a significant factor in influencing the earning level. Every year education increases hourly earnings by 2 percent. Every year experience also increases hourly earnings up to 9 percent at a decreasing rate. Compared to female, men's earnings are 25 percent higher even though their working hours are relatively the same. Informal labor, both men and women, require an array of services from government enabling them to either be gainfully working in the formal sector or running their own businesses. This can be achieve by providing an entrepreneurship development services and skills development training (Chant \& Pedwell 2008).

Meanwhile, the death of one of the family members reduces hourly earnings by up to 48 percent. However, when death occurs in informal households, the reduction in earnings is greater, which is 53 percent. This can be shown by the dummy coefficient of the interaction between informal and death. When informal variables interact with illness, the hourly earnings of informal household are 32 percent lower than those of formal ones. From the comparison of estimated formal and informal households, it can be inferred that the condition of informal households is relatively unfavorable compared to formal households when the shock occurs (ILO 2018). Extended or reformed social insurance scheme to cover more informal sector prevents this group to be vulnerable into poverty (Holmes \& Scott 2016).

\section{CONCLUSION}

The most common idiosyncratic shock of informal households is illness rather than death and job loss. Economically, the shock causes income disruption, which has implications for changes in labor market outcomes such as labor earnings and working hours. This study analyzed how the effects of illness, death, and job loss of any family member toward the changes in hourly earnings and working hours of 3,755 informal households in Indonesia. The informal households consisted of self-employed, self-employed with unpaid family workers, and causal workers in agriculture and non-agriculture households.

The hourly earnings of self-employed households and self-employed with unpaid family workers are very vulnerable to illness and job loss of any family member. Job loss causes a reduction in hourly earnings of selfemployed with unpaid workers up to 189 percent. Meanwhile, illness reduces hourly earnings by up to 82 percent. On the other hand, the number of working hours of those households remains unchanged when the shock reduces the hourly earnings significantly without any reduction in working hours, so it shows that these shocks deteriorate the welfare of informal 
self-employed households. This findings indicate the existence of Added Worker Effect (AWE) to mitigate the adverse effect of idiosyncratic shock.

The change in working hours by the shock only occurs in casual workers in agriculture households. They have to work 30 hours/week longer when there is one of a family member who is sick. This increase is equal to 75 percent of the average number of working hours of informal households. Unfortunately, the level of hourly earnings has not changed in response to this much longer working hours. It shows the compensating labor supply effect in order to maintain the previous level of living standard. Once again, it emphasizes that this informal household is very vulnerable to a decline in welfare caused by the shock.

Apart from weaknesses related to statistical issues arising from the small number case of each shock, the estimation results show that the shock causes a significant decline in the welfare of informal households in Indonesia. With the limited access to financial resources and insurance, in the short term, the shock might disrupt household allocations to human capital expenditure such as education, consumption, and health. If this potential problem cannot be overcome by an appropriate safety net scheme or any social protections, the shocks can potentially threaten the level of informal household welfare in the long run.

\section{REFERENCES}

Acuña, C., Acuña, H., \& Carrasco, D. 2019. Health shocks and the added worker effect: A life cycle approach. Journal of Applied Economics 22(1): 273-286. https://doi.org/10.10 80/15140326.2019.1613089

Ahmad, N., \& Aggarwal, K. 2017. Health shock, catastrophic expenditure and its consequences on welfare of the household engaged in informal sector. Journal of Public Health 25(6): 611-624. https://doi.org/10.1007/s10389017-0829-9

Ajefu, J. B. 2017. Income shocks, informal insurance mechanisms, and household consumption expenditure Micro-evidence from Nigeria. International Journal of Social Economics 44(12): 1818-1832. https://doi. org/10.1108/IJSE-04-2015-0094

Asfaw, A., \& von Braun, J. 2004. Is consumption insured against illness? Evidence on vulnerability of households to health shocks in rural Ethiopia. Economic Development and Cultural Change 53(1):115-129. https://doi. org/10.1086/423255

Atake, E. H. 2018. Health shocks in sub-Saharan Africa: Are the poor and uninsured households more vulnerable? Health Economics Review 8(1): 1-13. https://doi. org/10.1186/s13561-018-0210-x

Atake, E. H., \& Amendah, D. D. 2018. Porous safety net: Catastrophic health expenditure and its determinants among insured households in Togo. BMC Health Services Research 18(1). https://doi.org/10.1186/s12913018-2974-4
Beck, U., Singhal, S., \& Tarp, F. 2019. Commodity prices and intra-household labor allocation. American Journal of Agricultural Economics 101(2): 436-454.

Berchoux, T., Watmough, G. R., Hutton, C. W., \& Atkinson, P. M. 2019. Agricultural shocks and drivers of livelihood precariousness across Indian rural communities. Landscape and Urban Planning 189: 307-319. https:// doi.org/10.1016/j.landurbplan.2019.04.014

Berloffa, G., \& Modena, F. 2013. Income shocks, coping strategies, and consumption smoothing: An application to Indonesian data. Journal of Asian Economics 24: 158-171. https://doi.org/https://doi.org/10.1016/j. asieco.2012.11. 004

Cameron, L. A., \& Worswick, C. 2003. The Labor Market as a Smoothing Device: Labor Supply Responses to Crop Loss. Review of Development Economics 7(2): 327-341. https://doi.org/10.1111/1467-9361.00194

Chant, S., \& Pedwell, C. 2008. Women, gender and the informal economy: An assessment of ILO research and suggested ways forward. International Labor Office, Geneva.

Chen, M. A. 2001. Women and Informality: A Global Picture, the Global Movement. SAIS Review 21(1):71-82. https:// doi.org/10.1353/sais.2001.0007

Chen, M. A. 2007. Rethinking the Informal Economy: Linkages with the Formal Economy and the Formal Regulatory Environment (No. 46). DESA Working Paper. United Nations, Department of Economics and Social Affairs.

Cullen, J. B., \& Gruber, J. 2000. Does Unemployment Insurance Crowd out Spousal Labor Supply? Journal of Labor Economics 18(3): 546-572. https://doi. org/10.1086/209969

Dalton, M., \& LaFave, D. 2017. Mitigating the consequences of a health condition: The role of intra- and interhousehold assistance. Journal of Health Economics 53: 38-52. https://doi.org/10.1016/j.jhealeco.2017.02.001

Demenet, A. 2016. Health Shocks and Permanent Income Loss: the Household Business Channel. Working Papers, DIAL (Développement, Institutions et Mondialisation).

Eliason, M., \& Storrie, D. 2009. Does Job Loss Shorten Life? The Journal of Human Resources 44(2): 277-302.

Fitzsimons, E. 2007. The effects of risk on education in Indonesia. Economic Development and Cultural Change 56(1): 1-25. https://doi.org/10.1086/520560

García-Gómez, P. 2011. Institutions, health shocks and labour market outcomes across Europe. Journal of Health Economics 30(1): 200-213. https://doi.org/10.1016/j. jhealeco.2010.11.003

Genoni, M. E. 2012. Health shocks and consumption smoothing: Evidence from Indonesia. Economic Development and Cultural Change 60(3): 475-506. https://doi.org/10.1086/664019

Gertler, P., \& Gruber, J. 2002. Insuring Consumption Against Illness. American Economic Review 92(1): 51-70. https:// doi.org/10.1257/000282802760015603

Gertler, P., Levine, D. I., \& Moretti, E. 2009. Do microfinance programs help families insure consumption against illness? Health Economics 18(3): 257-273. https://doi. org/10.1002/hec. 1372 
Günther, I., \& Launov, A. 2012. Informal employment in developing countries: Opportunity or last resort? Journal of Development Economics 97(1): 88-98. https://doi. org/10.1016/j.jdeveco.2011.01.001

Holmes, R., \& Scott, L. 2016. Shaping policy for development Extending social insurance to informal workers A gender analysis (ODI Working Paper No. 438).

ILO. 2014. Transitioning from the informal to the formal economy. International Labor Office, Geneva. Retrieved from www.ilo.org/publns.

ILO. 2018. Women and men in the informal economy: a statistical picture. Geneva.

Kharisma, B. 2017. Idiosyncratic Shocks, Child Labor and School Attendance in Indonesia. MPRA Paper. University Library of Munich, Germany.

Kim, J., \& Prskawetz, A. 2010. External shocks, household consumption and fertility in Indonesia. Population Research and Policy Review 29(4): 503-526. https://doi. org/10.1007/s11113-009-9157-2

Kurniasih, E. P. 2017. Effect of economic growth on income inequality, labor absorption, and welfare. Economic Journal of Emerging Markets 9(2): 181-188. https://doi. org/10.20885/ejem.vol9.iss2.art7

Lechner, M., \& Vazquez-Alvarez, R. 2011. The effect of disability on labour market outcomes in Germany. Applied Economics 43(4): 389-412. https://doi. org/10.1080/00036840802599974

Mincer, J. 1974. Schooling, experience, and earnings. National Bureau of Economic Research; distributed by Columbia University Press.

Nazara, S. 2010. The informal economy in Indonesia: size, composition and evolution. International Labor Office, Jakarta.

Onisanwa, I. D., \& Olaniyan, O. 2019. Health shocks and consumption smoothing among rural households in Nigeria. Journal of Economics and Management 36: 44-70. https://doi.org/10.22367/jem.2019.36.03

Parinduri, R. A. 2014. Family Hardship and the Growth of Micro and Small Firms in Indonesia. Bulletin of Indonesian Economic Studies 50(1): 53-73. https://doi. org/10.1080/00074918.2014.896237

Pelkowski, J. M., \& Berger, M. C. 2004. The impact of health on employment, wages, and hours worked over the life cycle. Quarterly Review of Economics and Finance 44(1):102-121. https://doi.org/10.1016/j. qref.2003.08.002

Perry, G. E., Maloney, W. F., Arias, O. S., Fajnzylber, P., Mason, A. D., \& Saavedra-Chanduvi, J. 2007. Informality : Exit and Exclusion. World Bank Publications.
Pradhan, K. C., \& Mukherjee, S. 2018. Covariate and Idiosyncratic Shocks and Coping Strategies for Poor and Non-poor Rural Households in India. Journal of Quantitative Economics 16(1): 101-127. https://doi. org/10.1007/s40953-017-0073-8

Skoufias, E., Quisumbing, A. R., Gertler, P., \& Gruber, J. 2002. Insuring consumption against illness. American Economic Review 92(1): 51-70. https://doi. org/10.1257/000282802760015603

Sparrow, R., Poel, E. Van, Hadiwidjaja, G., Yumna, A., Warda, N., \& Suryahadi, A. 2014. Coping With The Economic Consequences Of Ill Health In Indonesia. Health Economics 23(6): 719-728.

Spence, M. 1973. Job Market Signaling. The Quarterly Journal of Economics (Vol. 87).

Swaminathan, S., \& Lillard, L. 2000. Health and labor market outcomes: evidence from Indonesia. University of Michigan. Retrieved from http://130.154.3.8/content/ $\mathrm{dam} / \mathrm{rand} / \mathrm{www} /$ external/labor/FLS/IFLS/papers/ HlthLabor.pdf

UNDP. 2011. Definition and Types of Shocks and Coping Strategies To Be Monitored. In Technical Workshop on "Monitoring Household Coping Strategies during Complex Crises", UNDP. Manila.

Wooldridge, J. M. 2013. Introductory Econometrics: A Modern Approach (5th ed.). Cengage.

World Bank. 2005. Improving Indonesia's Health Outcomes: Indonesia Policy Briefs. Jakarta.

Zhang, S. 2014. Wage shocks, household labor supply, and income instability. Journal of Population Economics 27(3): 767-796. https://doi.org/10.1007/s00148-0140507-y

Zucchelli, E., Jones, A. M., Rice, N., \& Harris, A. 2010. The Effects of Health Shocks on labour Market Exits: Evidence from the HILDA Survey. Australian Journal of Labour Economics 13(2):191-218.

Rokhedi Priyo Santoso*

Department of Economics

Universitas Islam Indonesia

Yogyakarta Indonesia 55283

E-mail: rokhedi@uii.ac.id

Jaka Sriyana

Department of Economics

Universitas Islam Indonesia

Yogyakarta Indonesia 55283

E-mail: jakasriyana@uii.ac.id

*Corresponding author 